\title{
Manfaat Ekonomi Sertifikasi Organik pada Usaha Tani Mete di Desa Dukuh, Kecamatan Kubu, Kabupaten Karangasem
}

\author{
BAGUS UTAMA EMTIEN, I WAYAN BUDIASA, \\ PUTU UDAYANI WIJAYANTI
}

\author{
Program Studi Agribisnis, Fakultas Pertanian, Universitas Udayana \\ Jalan PB Sudirman Denpasar 80232 \\ Email: utamaemtien@gmail.com \\ wba.agr@unud.ac.id
}

\begin{abstract}
The Economic Benefits of Organic Certification on Cashew Farming in the Dukuh Village, Kubu Sub-District of Karangasem Regency
\end{abstract}

Demand for organic cashew nuts in the international market is very high. The existence of organic certificate gives positive impact for cashew farmers, especially in increasing the selling price. Subak Abian Buana Kusuma is one of subak abian in Karangasem regency which conducts certified organic farming from certification institution of International Institute for Marketecology (IMO) Switzerland. Organic cashew certification is done by international certification agency IMO (Institute for Marketecology) Switzerland with the support of PT. PMA (Profil Mitra Abadi) and Dinas Kehutanan dan Perkebunan Kabupaten Karangasem to Subak Abian Buana Kusuma which is technically certified by ICS (Internal Control System). Revenue per hectare of certified organic farmers is Rp. 28,111,004,74 and non-organic farmers is Rp. 12,560,166.20, with a percentage of $119 \%$ greater income per hectare of organic farmers while the income per $\mathrm{kg}$ of organic farmers is Rp. 21,238.16 and non-organic farmers is $\mathrm{Rp} .11,721.14 / \mathrm{kg}$ with a percentage of $81 \%$ larger per kilogram of organic farmers. Premium price received by farmers is Rp.9000,00 with the cost of certification per $\mathrm{kg}$ is Rp. 163.00. Organic premium received by farmers is Rp. 9,517,02 / kg. The RC ratio of Subak Abian Buana Kusuma and Pandan Sari were 4.69 and 2.87 respectively, and the Profit Rate was $369 \%$ and $187 \%$, compared to $5 \%$ for $5 \%$ said to be very worthy to be cultivated. The value of $t$ arithmetic $>t$ table (2.34> 2.05), means that the income per hectare of organic cashew farms is greater than non-organic cashew nut production.

Keywords: organic certificate, cashew farming, revenue, $R C$ ratio, profit rate, comparative analysis

\section{Pendahuluan}

\subsection{Latar Belakang}

Sektor pertanian Indonesia mempunyai beberapa subsektor, diantaranya adalah subsektor perkebunan mempunyai fungsi yang strategis. Subsektor perkebunan terdapat satu komoditi yang cukup penting dalam perkebunan saat ini yaitu komoditi 
mete (Evizal, 2014). Jambu mete menjadi komoditi unggulan di beberapa provinsi di Indonesia salah satunya di Provinsi Bali. Jambu mete di Provinsi Bali sudah menjadi komoditas unggulan yang dibuktikan dengan diperolehnya sertifikat organik pada beberapa usahatani mete di Bali yang merupakan suatu bukti bahwa komoditi tersebut dihasilkan dengan menggunakan sistem organik.

Wilayah di Provinsi Bali yang paling berpotensi untuk pengembangan jambu mete adalah wilayah Kabupaten Karangasem dengan lahan yang sudah digunakan seluas 9.438 Ha (Disbun,2015), jauh melebihi lahan yang digunakan kabupatenkabupaten yang lainnya. Pusat pengembangan jambu mete di wilayah Kabupaten Karangasem adalah di Kecamatan Kubu. Sebagian areal wilayah Kubu sejak tahun 2008 telah berhasil mendapatkan sertifikat organik dari lembaga sertifikasi internasional dari Institute for Marketecology (IMO) Switzerland. Menurut data yang diperoleh dari Cashew Handbook 2014, tingkat pertumbuhan tahunan gabungan mete dari tahun 2004 sampai 2013 mencapai -2,88\%. Dampak dari adanya sertifikat organik, salah satunya yaitu peningkatan harga. Harga gelondongan mete non organik di tengkulak berkisar antara Rp. 16.500,-/Kg sampai Rp. 19.000/kg. dan untuk harga gelondongan mete organik tertinggi mencapai harga Rp 27.000/kg.

Penelitian dilakukan di salah satu desa di Kecamatan Kubu yaitu Desa Dukuh yang memiliki dua subak abian yang melakukan usaha tani organik dan non organik yaitu Subak Abian Buana Kusuma dan Subak Abian Pandan Sari. Penelitian ini dilakukan dengan asumsi masyarakat bahwa nilai ekonomis hasil usaha tani mete organik lebih tinggi dari usaha tani mete non organik, sedangkan usaha tani mete organik juga membutuhkan biaya yang tidak sedikit.

\subsection{Rumusan Masalah}

Masalah pada penelitian ini adalah: (1) Bagaimana proses tahapan sertifikasi organik pada usahatani mete di Desa Dukuh, Kecamatan Kubu, Kabupaten Karangasem. (2) Apakah usahatani mete organik memberikan manfaat ekonomi dibandingkan usaha tani mete konvensional di Desa Dukuh, Kecamatan Kubu, Karangasem.

\subsection{Tujuan Penelitian}

Tujuan penelitian adalah untuk: (1) mengetahui proses tahapan sertifikasi organik pada usahatani mete di Desa Dukuh, Kecamatan Kubu, Kabupaten Karangasem dan (2) mengetahui apakah usahatani mete organik memberikan manfaat ekonomi dibandingkan usaha tani mete konvensional di Desa Dukuh, Kecamatan Kubu, Karangasem.

\section{Metode Penelitian}

\subsection{Lokasi dan Waktu Penelitian}

Lokasi penelitian dilakukan di Subak Abian Buana Kusuma dan Subak Abian Pandan Sari yang berada di Desa Dukuh, Kecamatan Kubu, Kabupaten Karangasem. 
Pemilihan lokasi penelitian ditentukan dengan metode purposive sampling, dengan pertimbangan: (1) Subak Abian Buana Kusuma merupakan salah satu subak yang mengusahakan usaha tani mete organik dan Subak Abian Pandan Sari merupakan salah satu subak yang mengusahakan usaha mete non organik atau konvensional. (2) belum pernah dilakukan penelitian serupa pada Subak Abian yang terdapat di Desa Dukuh, Kecamatan Kubu, Kabupaten Karangasem.

\subsection{Metode Pengumpulan Data}

\subsubsection{Jenis dan sumber data}

Jenis data pada penelitian ini adalah data kualitatif dan data kuantitatif. Data kuantitatif adalah data yang dapat dihitung dan dalam bentuk angka-angka yang dapat dihitung dengan satuan tertentu seperti data pendapatan, dan biaya produksi. Data kualitatif adalah data yang tidak dalam bentuk angka tetapi merupakan uraian maupun penjelasan yang tidak dapat dihitung. Data kualitatif ini sifatnya menunjang dan berhubungan dengan masalah yang diteliti, seperti gambaran umum lokasi penelitian dan kendala umum.

\subsubsection{Pengumpulan Data}

Pengumpulan data pada penelitian ini dengan menggunakan studi literatur, observasi, dan survei.

\subsection{Populasi dan Sampel Penelitian}

Teknik sampel yang digunakan pada penelitian ini adalah dengan proportional random sampling. Populasi dalam penelitian ini adalah seluruh anggota kelompok usaha tani mete organik yaitu Subak Abian Buana Kusuma yang berjumlah 87 orang dan seluruh anggota kelompok usaha tani mete non organik yaitu Subak Abian Pandan Sari yang berjumlah 93 orang sehingga jumlah sampel yang digunakan masing-masing sebanyak 30 orang.

\subsection{Variabel dan Pengukuran}

Variable yang digunakan dalam penelitian ini adalah pendapatan usaha tani mete organik dan usaha tani mete non organik di Desa Dukuh, Kecamatan Kubu. Indikator yang digunakan adalah biaya investasi, biaya tetap, dan biaya variabel dengan menggunakan parameter jumlah/tahun dan pengukuran Rp/tahun. Indikator jumlah produksi menggunakan parameter jumlah/tahun dan pengukuran Rp/tahun. Indikator harga menggunakan parameter jumlah/tahun dan pengukuran Rp/tahun.

\subsection{Metode Analisis Data}

Metode analisis data yang digunakan pada penelitian ini adalah analisis pendapatan, analisis kelayakan usaha tani, dan analisis komparatif (uji t). 


\section{Hasil dan Pembahasan}

\subsection{Standar Internal Organik}

Cakupan sertifikat dibuat mengacu pada EU-Regulation (EC) No. 834/2007 dan EU-Regulation (EC) No. 889/2008. Kebijakan standar internal organik (IMO, 2007 dalam Pedoman ICS 2013) telah disusun oleh petani melalui subak abian sebagai acuan untuk melakukan kontrol internal dalam subak abian sebagai peserta program sertifikasi organik. Penyusunan dilakukan secara bersama-sama antara pengurus subak abian dan Inspektor Internal lembaga ICS yang difasilitasi oleh staf PT Profil Mitra Abadi dan unsur pemerintah Dinas Kehutanan dan Perkebunan Kab. Karangasem.

\subsection{Tahapan Sertifikasi Organik}

Proses tahapan sertifikasi organik pada usahatani mete di Desa Dukuh adalah petani mendaftar dan melakukan prosedur administrasi peserta mete organik. Setelah ICS merangkum petani yang mengajukan sertifikasi, kemudian dokumen tersebut dikirim ke PT. PMA (Profil Mitra Abadi) yang langsung mengirim data tersebut ke pihak otoritas sertifikasi yaitu IMO Swiss. Pihak IMO akan melakukan keputusan akhir tentang petani yang disetujui atau tidak menjadi peserta program sertifikasi mete organik. Setiap tahunnya dilakukan inspeksi internal oleh ICS (Internal Control System). Hal terakhir dalam proses sertifikasi ini adalah melakukan kegiatan jual beli kepada PT. PMA.

\subsection{Pendapatan Usaha Tani Mete di Desa Dukuh}

Sertifikat organik yang diterima Subak Abian Buana Kusuma adalah sertifikat organik dari IMO Swiss dengan Nomor. 26510 dengan masa validitas dari tanggal 26 November 2015 sampai dengan 31 Maret 2017. Petani di Desa Dukuh berhasil melakukan dua kali panen dalam periode tersebut yaitu pada bulan Desember 2015 dan Oktober 2016.

Penerimaan yang diterima petani mete di Subak Abian Buana Kusuma lebih besar daripada penerimaan petani mete non organik di Subak Abian Pandan Sari dengan selisih sebesar Rp 8.038.520,92/ha. Produksi mete organik selama dua kali panen sebesar 1.323,61 kg/ha dengan harga yang diterima sebesar Rp. 27.000,00/kg, sedangkan produksi mete non organik selama dua kali panen sebesar 1,092,24 kg/ha dengan harga yang diterima sebesar Rp. 18.000,00/kg. Petani mete organik mendapatkan nilai jual produksi lebih besar daripada petani non organik yaitu mengalami peningkatan sebanyak 50\% dengan harga sebesar Rp. 9.000,00/kg. Selisih harga tersebut merupakan premium price yang diterima oleh petani.

Sesuai dengan Surat Perjanjian Kerja (Kontrak) Nomor : 027/01/S.Perj/ Dishutbun/2015, rincian anggaran biaya yang diperlukan untuk menginspeksi dan mensertifikasi adalah Rp. 150.000.000,00. Biaya ini disubsidi oleh Pemerintah Kabupaten Karangasem sebesar Rp. 50.000.000,00 dan PT. PMA (Profil Mitra Abadi) Jakarta yang telah didukung oleh IMO-Swiss dengan biaya sebesar Rp. 
100.000.000,00. Aktivitas pengawasan tahunan atau surveillance memerlukan biaya Rp. 50.000.000,00, sehingga total biaya sertifikasi tersebut adalah Rp. 200.000.000,00. Biaya sertifikasi ini meliputi 5 subak abian yaitu Subak Abian Buana Kusuma, Giri Celagi, Tunas Mekar, Mekar Sari, dan Suli Gading sehingga pembebanan biaya sertifikasi per subak abian sebesar Rp.40.000.000,00. Dengan masing-masing petani di bebani biaya sebesar $\mathrm{Rp} 459.8770,00$. Total biaya sertifikasinya adalah sebesar Rp. 13.793.103,00, yang artinya biaya sertifikasi per hektar sebesar Rp. 215.652,00 dan per kg sebesar Rp. 163,00.

Secara keseluruhan total biaya usaha tani mete organik lebih besar daripada biaya usaha tani mete non organik, dengan biaya usaha tani mete organik sebesar Rp. 487.786.136,78, yang berarti biaya per hektar dan biaya per kg adalah sebesar Rp 3,813,212.45 dan Rp. 5,761.84. Biaya usaha tani mete non organik sebesar Rp. 247.575.500,00, yang berarti biaya per hektar dan biaya per kg adalah sebesar Rp. 3.429.023,55dan Rp. 6.278,86. Biaya per hektar usaha tani mete organik lebih besar $11 \%$ daripada usaha tani mete non organik, namun biaya per kg usaha tani mete non organik lebih besar $9 \%$ daripada usaha tani non organik. Hal ini disebabkan oleh hasil produksi usaha tani mete organik lebih banyak daripada produksi usaha tani mete non organik.

Menurut Rahardja dan Mandala (2006), perusahaan dikatakan memperoleh keuntungan atau laba apabila nilai $\Pi$ positif $(\Pi>0)$ dimana TR $>$ TC. Pendapatan $(\Pi)$ merupakan selisih antara penerimaan perusahaan dengan biaya total. Pendapatan Usahatani Mete di Desa Dukuh dapat dilihat pada Tabel 1.

Tabel 1.

Pendapatan Usahatani Mete di Desa Dukuh, Kecamatan Kubu, Kabupaten Karangasem

\begin{tabular}{lrr}
\hline \multicolumn{1}{c}{ Uraian } & (organik) & (non organik) \\
\hline Total Penerimaan $(\mathrm{TR})$ & $2.285 .766 .000,00$ & $709.740 .000,00$ \\
Total Biaya $(\mathrm{TC})$ & $487.786 .136,78$ & $247.575 .500,00$ \\
\hline Pendapatan $(\Pi)$ & $1.797 .979 .863,22$ & $462.164 .500,00$ \\
Pendapatan per Hektar (Rp/ha) & $14.055 .502,37$ & $6.401 .170,36$ \\
Pendapatan per kg (Rp/kg) & $21.238,16$ & $11.721,14$ \\
\hline
\end{tabular}

Sumber : data primer diolah

Berdasarkan Tabel 1, pendapatan per hektar petani organik adalah Rp. 14,055,502.37 dan petani non organik adalah Rp. 6,401,170.36 dengan persentase sebesar $119 \%$ lebih besar pendapatan per hektar petani organik, sedangkan pendapatan per kg petani organik adalah Rp. 21.238,16 dan petani non organik adalah Rp. 11.721,14 dengan persentase sebesar $81 \%$ lebih besar pedapatan per kg petani organik. Organic premium yang diterima petani adalah sebesar Rp. 9.517,02/kg. Hal ini berarti, Subak Abian Buana Kusuma yang melakukan usaha tani 
tani mete organik yang sudah besertifikat lebih menguntungkan dari usaha tani mete non organik yang dalam hal ini adalah Subak Abian Pandan Sari.

\subsection{Analisis Kelayakan Usaha Tani Mete di Desa Dukuh}

Menurut Darsono (2008) analisis rasio dilakukan untuk mengetahui kelayakan usaha tani yang diperoleh dari perbandingan antara penerimaan usaha tani (revenue) dengan biaya usaha tani (cost). Usaha tani mete organik pada Subak Abian Buana Kusuma dan usaha tani mete non organik pada Subak Abian Pandan Sari dapat dikatakan layak untuk dijalankan. Hal ini dikarenakan hasil RC rasio yang menunjukkan angka lebih besar dari 1 sehingga usaha tani tersebut dikatakan layak untuk diusahakan. Hasil RC rasio petani non organik sebesar 2,87 dan petani organik yang memilki RC rasio sebesar 4,69. Usaha tani jambu mete organik menunjukan persentase sebesar 369\% dan non organik menunjukan persentase sebesar 187\%. Hal ini dikarenakan persentase profit rate menunjukkan angka lebih besar dari rata-rata inflasi selama lima tahun terakhir yaitu $5 \%$ (BPS, 2017), sehingga usaha tani tersebut sangat menguntungkan atau profitable yaitu usaha tani mete tersebut sangat layak untuk diusahakan.

\subsection{Analisis Komparatif (Uji-t)}

Menurut Tenaya dkk. (1988), statistik yang digunakan untuk menganalisis perbedaan diantara dua kelompok adalah uji-t sampelPerhitungan yang dilakukan bertujuan untuk mengetahui apakah ada perbedaan yang nyata atau signifikan antara rata-rata pendapatan per hektar Subak Abian Buana Kusuma yang mengusahakan usaha tani mete organik dan Subak Abian Pandan Sari yang mengusahakan usaha tani mete non organik. Berdasarkan hasil perhitungan yang dilakukan, hasil $\mathrm{f}$ hitung adalah 3,92 dan $\mathrm{f}$ tabel sebesar 0,05, yang berarti varian A ( pendapatan per hektar Subak Abian Buana Kusuma) memiliki perbedaan dengan varian B (pendapatan per hektar Subak Abian Pandan Sari). Varian A berbeda dengan varian B sehingga nilai t hitung yang diperoleh sebesar 2,34 dan nilai t tabel sebesar 2,05, sehingga t hitung lebih besar daripada $\mathrm{t}$ tabel. Artinya bahwa ada perbedaan yang nyata antara pendapatan per hektar petani mete organik di Subak Abian Buana Kusuma yang melakukan usaha tani mete organik dengan pendapatan per hektar petani mete non organik di Subak Abian Pandan Sari yang melakukan usaha tani mete non organik dalam satu siklus sertifikasi.

\subsection{Manfaat Ekonomi Sertifikasi Organik bagi Petani}

Beberapa manfaat ekonomi yang dirasakan petani tersebut adalah sebagai berikut;

1. Tingginya pendapatan petani jambu mete organik bersertifikat disebabkan oleh beberapa hal, yaitu perbedaan harga jual gelondong mete organik dan non organik. Harga jual gelondong mete organik lebih tinggi dibandingkan non 
organik, yaitu lebih tinggi $\mathrm{Rp} \mathrm{9.000/kg} \mathrm{dan} \mathrm{rata-rata} \mathrm{hasil} \mathrm{produksi} \mathrm{lebih} \mathrm{tinggi}$ karena masa panennya cukup tua.

2. Berdasarkan fakta dilapangan, petani mete organik dalam hal ini petani Subak Abian Buana Kusama, dipersiapkan dalam menyelenggarakan sertifikasi mete organik dengan proses sistem yang panjang melalui berbagai macam pembinaan. Pembinaan dilakukan oleh pemerintah, perusahaan, dan otoritas sertifikasi yaitu IMO Swiss. Implementasi sistem pembinaan tersebut sudah pasti menambah pengetahuan, wawasan, pengalaman, dan keterampilan petani.

3. Tanaman mete banyak terserang JAP (Jamur Akar Putih) karena tanah di wilayah Kecamatan Kubu cenderung berpasir dan kekurangan humus. Pertanian organik sangat cocok dikembangkan di wilayah tersebut. Tanah yang subur banyak mengandung humus sehingga pertumbuhan tanaman menjadi lebih baik.

\section{$4 \quad$ Kesimpulan dan Saran}

\subsection{Kesimpulan}

Berdasarkan tujuan dan hasil pembahasan, maka diperoleh beberapa kesimpulan dan saran sebagai berikut:

1. Proses sertifikasi mete organik membutuhkan waktu dua tahun masa konversi dan dua tahun masa berlaku sertifikasi. Sertifikasi mete organik dilakukan oleh lembaga sertifikasi internasional yaitu IMO (Institute for Marketecology) Swiss dengan dukungan biaya dari PT PMA (Profil Mitra Abadi) dan Dinas Kehutanan dan Perkebunan Kabupaten Karangasem kepada Subak Abian Buana Kusuma yang secara teknis sertifikasi dikerjakan oleh ICS (Internal Control System).

2. Pendapatan per hektar petani organik bersertifikat adalah $\mathrm{Rp} 14,055,502.37$ dan petani non organik adalah Rp 6.401.170,36, dengan persentase sebesar $119 \%$ lebih besar pendapatan per hektar petani organik sedangkan pendapatan per $\mathrm{kg}$ petani organik adalah $\mathrm{Rp} 21.238,16$ dan petani non organik adalah Rp 11.721,14/kg dengan persentase sebesar $81 \%$ lebih besar pedapatan per kg petani organik. Premium price yang diterima petani adalah sebesar Rp 9000,00 dengan biaya sertifikasi per kg adalah Rp 163,00. Organic premium yang diterima petani adalah sebesar $\mathrm{Rp} 9.517,02 / \mathrm{kg}$.

3. Hasil RC rasio Subak Abian Buana Kusuma dan Pandan Sari masing-masing adalah 4,69 dan 2,87, kemudian hasil profit rate adalah $369 \%$ dan $187 \%$, yang dibandingkan dengan rata-rata inflasi selama lima tahun yaitu $5 \%$ sehingga usaha tani tersebut dikatakan sangat layak untuk diusahakan. Nilai t hitung > t tabel $(2,34>2,05)$, artinya bahwa pendapatan per hektar usaha tani mete organik lebih besar dari pendapatan usaha tani mete non organik. 


\subsection{Saran}

Saran yang dapat diberikan adalah sebagai berikut.

1. Pemerintah Kabupaten Karangasem harus lebih mensosialisasikan kepada petani mete agar membudidayakan usaha tani mete organik karena mete organik tersebut sangat menguntungkan.

2. Petani yang menjalankan usaha tani mete organik harus disiplin dalam menjalankan Standar Internal Organik yang diterapkan, sehingga sertifikat tersebut dapat di pertahankan.

\section{$5 \quad$ Ucapan Terimakasih}

Ucapan terimakasih ini penulis tunjukan kepada seluruh pihak yang telah membantu dalam pelaksanaan penelitian hingga karya ilmiah ini dapat dipublikasikan di e-jurnal.

\section{Daftar Pustaka}

Badan Pusat Statistik. 2017. Tingkat Inflasi Indonesia. [Artikel on-line]. https://www.bps.go.id/linkTabelStatis/view/id/907 diakses pada 14 Juni 2017.

Budiasa, I Wayan. 2014. Organic Farming as an Innovative Farming System Development Model Toward Sustainabke Agriculture in Bali. Asian Journal of Agriculture and Development. Vol. 11 No.1.

Cashew Handbook. 2014. Global Perspective. [Artikel on-line]. http://www.cachewinfo.com/cashewhandbook2014.pdf diakses pada 14 Juni 2015.

Darsono, 2008. Hubungan Perceived Service Quality dan Loyalitas: Peran Trust dan Satisfaction sebagai Mediator. Surabaya: The 2 nd National Conference UKWMS.

Dinas Kehutanan dan Perkebunan Provinsi Bali. 2015. Luas Areal dan Produksi Jambu Mete di Kabupaten Karangasem. Bali.

Dinas Kehutanan dan Perkebunan Kabupaten Karangasem. 2015. Surat Perjanjian Kerja (Kontrak) Nomor : 027/01/S.Perj/Dishutbun/20. Bali.

Evizal, Rusdi. 2014. Dasar-dasar Produksi Perkebunan. Yogyakarta: Graha Ilmu. Management Board of Farmers Group, The ICS. 2013. Pedoman ICS. Jakarta: IMO

Rahardja, Prathama dan Mandala Manurung. 2006. Teori Ekonomi Mikro- Suatu Pengantar (Edisi Ketiga). Jakarta : Fakultas Ekonomi, Universitas Indonesia.

Tenaya, I Made, I Dewa Gede Raka, I Dewa Gede Agung. 1988. Bahan Kuliah Rancangan Percobaan I Rancangan Dasar. Lab Statistika FP UNUD: Denpasar. 